\title{
Sistem Pendukung Keputusan Penentuan Merek Smartphone Terbaik Dalam Mendukung Belajar Online Mahasiswa Era Covid-19 Menggunakan Metode PSI (Preference Selection Index)
}

\author{
Wan Mariatul Kifti ${ }^{1,}$, Irene Hasian ${ }^{2}$ \\ ${ }^{1}$ Program Studi Sistem Informasi, STMIK Royal Kisaran, Kisaran, Indonesia \\ ${ }^{2}$ Program Studi Desain Komunikasi Visual, Sekolah Tinggi Media Komunikasi Trisakti, Jakarta, Indonesia \\ Email: 1,*kifti.inti@gmail.com, 2irene.hasian@trisaktimultimedia.ac.id \\ Email Penulis Korespondensi: kifti.inti@gmail.com
}

\begin{abstract}
Abstrak-Era pandemi Covid-19 mengakibatkan masyarakat harus melakukan aktivitas dengan menjaga jarak satu dengan yang lainnya demi tercapainya pemutusan tali penyebaran virus Covid-19, aktivitas tersebut mengakibatkan pemerintah mengeluarkan surat keputusan terutama kepada dinas pendidikan untuk melakukan pembelajaran secara online karena sekolah maupun perguruan tinggi merupakan salah satu tempat yang memiliki potensi besar mudahnya terjadi penularan, pembelajaran online membuat semua pelajar wajib memiliki smartphone atau android sehingga mempermudah akses pelajar dalam melakukan pembelajaran online, perlu dilakukan penentuan merek smartphone terbaik dengan kriteria pembelian terbanyak, harga, kapasitas yang dimiiki smartphone dan tahun keluaran yang nantinya menjadi literature review pelajar dan orang tua pelajar untuk lebih selektif memilih sesuai dengan keinginan dan kebutuhan masing-masing pengguna dengan bantuan sistem pendukung keputusan dan penerapan terhadap metode PSI (Preference Selection Index), dan didapatkan hasil dengan perolehan nilai tertinggi pada smartphone xiaomi dengan nilai tertinggi sebesar 0,327332 , proses penilaian lebih adil dan proses pengambilan keputusan yang cepat.
\end{abstract}

Kata Kunci: SPK; Merek Smartphone; Belajar Online; PSI

\begin{abstract}
The era of the Covid-19 pandemic has resulted in people having to carry out activities by keeping their distance from one another in order to achieve the termination of the spread of the Covid-19 virus, this activity resulted in the government issuing a decree, especially to the education office to conduct online learning because schools and universities is one of the places that has great potential for easy transmission, online learning makes all students obliged to have a smartphone or android so that it makes it easier for students to access online learning, it is necessary to determine the best smartphone brand with the most purchase criteria, price, capacity owned by smartphone and year. output which will later become a literature review of students and parents of students to be more selective in choosing according to the wishes and needs of each user with the help of a decision support system and the application of the PSI method (Preference Selection Index). rence selection index), and the results obtained with the highest score on the xiaomi smartphone with the highest score of 0,327332 , the assessment process is fairer and the decision-making process is fast.
\end{abstract}

Keywords: SPK; Smartphone Brand; Online Learning; PSI

\section{PENDAHULUAN}

Pandemi covid-19 membuat masyarakat dunia terutama Negara Indonesia harus beradaptasi dengan kecanggihan teknologi mulai dari pemanfaatan laptop, smartphone dan jaringan koneksi internet dikarenakan harus terus menjaga jarak dan tetap dirumah demi mencegah terjadinya jumlah pasien yang terkontaminasi covid-19[1]. hal tersebut menyebabkan pemerintah menghimbang pusat keramaian masyarakat seperti supermarket, bioskop tempat wisata instansi pemerintahan, industri maupun perusahaan besar dan sektor pendidikan harus melakukan pekerjaan dengan menjaga jarak dan memberikan himbauan untuk lebih baik di rumah saja untuk keamanan masyarakat diseluruh negeri. Salah satu kegiatan yang mengikuti himbauan pemerintah dan masih dijalani hingga hari ini adalah sekolahan dan perguruan tinggi yang membuat para pelajar harus melakukan proses pembelajaran dan administrasi harus dijalankan dengan cara daring atau secara online [2].

Pembelajaran online tentunya memerlukan sebuah teknologi seperti smartphone sebagai media pembelajaran dimana setiap kegiatan dan setiap transaksi yang berhubungan dengan sekolah maupun pendidikan tinggi tentu saja dilakukan menggunakan media online [3], tetapi tidak semua masyarakat mampu membeli sebuah smartphone dikarenakan harga smartphone yang cukup tinggi disaat krisis ekonomi yang disebabkan oleh masa pandemi. Pembelian smarphone harus sesuai dengan pemanfaatan dan kebutuhan dan budget masyarakat terutama pada kalangan pelajar yang duduk di perguruan tinggi atau mahasiswa, sering terjadi pembelian smartphone dilakukan hanya untuk mendukung alat komunikasi satu dengan yang lainnya, berbeda dengan halnya penggunaan smartphone dalam mengakses pembelajaran mahasiswa yang harus memiliki kapasitas dan kualitas yang cukup tinggi[4].

Perlunya dilakukan pemilihan terhadap smartphone merupakan suatu hal yang penting dikarenakan jika salah memilih smartphone akan terjadi penyesalan dikemudian dan banyaknya jenis smartphone membuat sulitnya seseorang menentukan jenis smartphone yang bagaimana yang akan dibeli, digunakan sistem pendukung keputusan dalam menentukan merek smartphone terbaik untuk mempermudah pembeli dalam menentukan barang yang ingin dibeli sesuai dengan budget, kapasitas dan kebutuhan pembeli, dilakukan pemilihan dengan menggunakan sistem yaitu sistem pendukung keputusan dikarenakan akan lebih mempermudah dalam menemukan masalah dan menyelesaikan masalah yang ditemukan[5]. Pada sistem 
pendukung keputusan dibutuhkan kritetria sebagai bahan pertimbangan dalam pemilihan merek smartphone yang terbaik dengan masing-masing kriteria yang tentunya memiliki bobot sebagai bahan pertimbangan dan penentu kuantitas terhadap masing-masing kriteria sehingga lebih menguatkan alasan dalam pemilihan dan penilaian objek tertentu[6].

Sistem pendukung keputusan pada penelitian ini menggunakan metode PSI (Preference slection index) dimana metode ini merupakan metode yang sangat sederhana dalam penyelesaian kasus dalam membantu proses hasil pengambilan keputusan, berdasarkan penelitian terdahulu penggunaan metode ini dianggap sangat berpengaruh dalam pengambilan keputusan dengan hasil yang sangat maksimal, setiap nilai tertinggi merupakan hasil dari rangking yang dapat dipercaya sebagai nilai hasil keputusan yang dapat diajukan sebagai pilihan utama, Pada penelitian terdahulu metode PSI (Preference slection index) digunakan dalam membantu banyak penyelesaian permasalahan seperti dalam penentukan siswa pertukaran pelajar, pada tahapan tersebut harus benar-benar mendapatkan hasil terbaik dengan nilai tertinggi dikarenakan membawa nama baik sekolah yang menjadi simbol diri pelajar yang terpilih. Penelitian lain menyebutkan metode PSI sangat membantu dalam proses menentukan daerah prioritas yang akan dibagun, penelitian lainnya metode ini membantu dalam memilih siswa penerima bantuan dana boss dan membantu dalam prose menentukan supervisor terbaik yang akan diberikan reward, hasil dari penelitian menyatakan metode PSI (Preference slection index) merupakan metode yang sangat bermanfaat serta sederhana dalam penggunaannya dengan hasil terpat dan terpecaya [7]-[11].

\section{METODOLOGI PENELITIAN}

Metodologi penelitian mengkaitkan kepada teoristis dan tahapan yang dilakukan dalam menyelesaikan permasalahan dalam sebuah penelitian mulai dari pengambilan data, keseluruhan teoristis pada penelitian hingga metode-metode yang digunakan yang bertujuan agar peneliti mampu menyelesaikan penelitiannya dengan baik dan benar hingga mencapai tujuan penelitian dalam menyelesaikan permasalahan yang ditujukan[12].

\subsection{Sistem Pendukung Keputusan}

Sistem pendukung keputusan merupakan sebuah sistem yang dirancang untuk mempermudah seeorang atau pimpinan dalam mengambil keputusan yang dilakukan secara tersistem agar mendapatkan hasil dari sistem mampu mengolah data yang sangat banyak dalam sebuah sistem dengan menerapkan metode dalam pengembangan sistem yang bertujuan agar data yang diolah mendapatkan hasil yang tepat [13]-[17].

\subsection{Belajar Online}

Belajar online merupakan cara belajar baru yang digunakan dengan memanfaatkan teknologi dan jaringan, berbagai jenis penggunaan media dalam pembelajaran berupa sebuah aplikasi yang tersedia untuk mendukung pembelajaran, dan meningkatkan pengetahuan terhadap penggunanya, fungsi dari pembelajaran online salah satunya untuk membuat waktu dan proses belajar tidak mengenal jarak dan tempat, pembelajaran online sangat bermanfaat dilakukan ketika masa pandemi covid-19 dikarenakan adanya pembelajaran online memudahkan mahasiswa dan pelajar seluruh dunia mampu untuk terus menjalankan kegiatan belajar dan mengajar[18].

\subsection{Metode Preference Selection Index (PSI)}

Metode Preference Selection Index merupakan salah satu dari metode sistem pendukung keputusan yang menggunakan tahapan-tahapan sederhana dalam penyelesaian masalahnya dan mengambil nilai tertinggi sebagai nilai alternatif rekomendasi pada metode ini dimana setiap langkah-langkah menggunakan bobot tertentu dan sesuai dengan spesifikasi masing-masing alternatif. dan berikut merupakan tahapan dalam pengambilan keputusan menggunakan metode PSI (Preference slection index) [19]-[22]:

1. Tentukan alternatif dan kriteria tujuan

2. Matriks keputusan yang sebelumnya telah ditentukan masing-masing nilai awal dalam penyeleksian data yang akan digunakan

$$
\mathrm{Xij}=\left[\begin{array}{cccc}
x 11 & x 12 & \ldots & x 1 n \\
x 21 & x 22 & \ldots & x 2 n \\
\vdots & & & \\
x m 1 & x m 2 & \ldots & x m n
\end{array}\right] .
$$

3. Normalisasi matriks keputusan

Jiks atribut benefit maka menggunakan rumus berikut:

$$
N_{i j}=\frac{X_{i j}}{X_{j}^{\max }}
$$

Jika atributnya cost rumus sebagai berikut: 


$$
N_{i j}=\frac{x_{j}^{\min }}{X_{i j}}
$$

4. Lakukan pecarian rata-rata terhadap nilai

Dalam rumusan pencarian nilai ini dihitung dengan persamaan berikut:

$\mathrm{N}=\frac{1}{n} \sum_{i=1}^{n} N_{i j}$

5. Menghitung variasi preferensi

Pada tahapan ini ditemukan sebuah nilai variasi preferensi dengan menggunakan rumus sebagai berikut:

$\phi_{j}=\sum n_{i=1}\left[N_{11}-N\right]^{2}$

6. Mencari data penyimpangan terhadap nilai preferensi

$\Omega \mathrm{j}=1-\emptyset j$

7. Menentukan pembobotan terhadap kriteria.

$\omega_{j}=\frac{j}{\sum_{j=1}^{m} \Omega_{j}}$.

Nilai total keseluruhan kriteria bobot dari semua atribut harus satu, contoh

$\sum_{j=1}^{m} \Omega_{j}=1$.

8. Hitung PSI $\left(\theta_{\mathrm{i}}\right)$

Menghitung mencari nilai PSI menggunakan rumus sebagai berikut:

$\theta i=\sum^{m_{j=1}} X_{i j} \omega_{j}$

9. Pilih alternatif yang sesuai berdasarkan nilai tertinggi untuk menjadi kandidat pilihan merek smartphone terbaik

\section{HASIL DAN PEMBAHASAN}

Penelitian ini menggunakan masing-masing mahasiswa sebagai data objek untuk mengetahui keinginan terhadap kepemilikan merek smartphone yang diingnkan dengan kriteria harga, ram, kamera, ukuran layar, merek, dengan masing-masing botot atau nilai terhadap persentase keunggulan yang dimiliki oleh alternatif, pada kasus ini digunakan penerapan sistem pendukung keputusan terhadap pendekatan

\subsection{Data Alternatif}

Berikut merupakan daftar handphone yang

Tabel 2. Alternatif

\begin{tabular}{cc}
\hline Kode & Nama Alternatif \\
\hline A1 & Infinix \\
A2 & Xiaomi \\
A3 & Samsung \\
A4 & Vivo \\
A5 & Oppo \\
A6 & Realme \\
A7 & sonny \\
A8 & Iphone \\
\hline
\end{tabular}

\subsection{Menentukan Kriteria}

Berikut merupakan kriteria pendukung terhadap proses pengambilan keputusan menggunakan metode PSI

Tabel 3. Kriteria

\begin{tabular}{ccc}
\hline Kriteria & Keterangan & Jenis \\
\hline C1 & Harga & cost \\
C2 & Ukuran layar & benefit \\
C3 & RAM & benefit \\
C4 & Baterai & benefit \\
C5 & Memori Internal & benefit \\
\hline
\end{tabular}


JURNAL MEDIA INFORMATIKA BUDIDARMA

Volume 5, Nomor 3, Juli 2021, Page 762-768

ISSN 2614-5278 (media cetak), ISSN 2548-8368 (media online)

Available Online at https://ejurnal.stmik-budidarma.ac.id/index.php/mib DOI 10.30865/mib.v5i3.2994

\subsection{Alternatif untuk Kriteria}

Tabel 4. Alternatif Terhadap Kriterianu

\begin{tabular}{ccccccc}
\hline Alternatif & \multicolumn{2}{c}{ Harga } & $\begin{array}{c}\text { Ukuran } \\
\text { layar }\end{array}$ & RAM & Baterai & $\begin{array}{c}\text { Memori } \\
\text { Internal }\end{array}$ \\
\hline Infinix & $\mathrm{Rp}$ & 1.600 .000 & $6 \mathrm{inc}$ & $3 \mathrm{~GB}$ & $5200 \mathrm{mAh}$ & $32 \mathrm{~GB}$ \\
Xiaomi & $\mathrm{Rp}$ & 2.500 .000 & $6.5 \mathrm{inc}$ & $6 \mathrm{~GB}$ & $6000 \mathrm{mAh}$ & $128 \mathrm{~GB}$ \\
Samsung & $\mathrm{Rp}$ & 3.000 .000 & $5.5 \mathrm{inc}$ & $2 \mathrm{~GB}$ & $5000 \mathrm{mAh}$ & $64 \mathrm{~GB}$ \\
Vivo & $\mathrm{Rp}$ & 2.700 .000 & $6.5 \mathrm{inc}$ & $4 \mathrm{~GB}$ & $4000 \mathrm{mAh}$ & $64 \mathrm{~GB}$ \\
Oppo & $\mathrm{Rp}$ & 3.690 .000 & $6.5 \mathrm{inc}$ & $3 \mathrm{~GB}$ & $6000 \mathrm{mAh}$ & $64 \mathrm{~GB}$ \\
Realme & $\mathrm{Rp}$ & 2.700 .000 & $6 \mathrm{inc}$ & $4 \mathrm{~GB}$ & $4000 \mathrm{mAh}$ & $32 \mathrm{~GB}$ \\
huwawei & $\mathrm{Rp}$ & 4.000 .000 & $5.5 \mathrm{inc}$ & $4 \mathrm{~GB}$ & $5000 \mathrm{mAh}$ & $64 \mathrm{~GB}$ \\
Iphone & $\mathrm{Rp}$ & 6.000 .000 & $4 \mathrm{inc}$ & $8 \mathrm{~GB}$ & $4000 \mathrm{mAh}$ & $64 \mathrm{~GB}$ \\
\hline
\end{tabular}

Berdasarkan tabel di atas, berikut tabel rating kecocokan dari masing-masing alternatif pada kriteria yang sudah ditentukan.

Tabel 5. Nilai Alternatif pada Kriteria

\begin{tabular}{cccccc}
\hline Alternatif & C1 & C2 & C3 & C4 & C5 \\
\hline Infinix & 1.600 .000 & 6 & 3 & 5200 & 32 \\
Xiaomi & 2.200 .000 & 6.5 & 6 & 6000 & 128 \\
Samsung & 3.000 .000 & 5.5 & 2 & 5000 & 64 \\
Vivo & 2.700 .000 & 6.5 & 4 & 4000 & 64 \\
Oppo & 3.690 .000 & 6.5 & 3 & 6000 & 64 \\
Realme & 2.700 .000 & 6 & 4 & 4000 & 32 \\
huwawei & 4.000 .000 & 5.5 & 4 & 5000 & 64 \\
Iphone & 6.000 .000 & 4 & 8 & 4000 & 64 \\
\hline
\end{tabular}

Untuk menyelesaikan masalah diatas menggunakan metode PSI maka harus mengikuti lan gkah-langkah yang sudah di jelaskan sebelumnya.

Tabel 6. Matriks Keputusan

\begin{tabular}{cccccc}
\hline Alternatif & C1 & C2 & C3 & C4 & C5 \\
\hline A1 & 1.600 .000 & 6 & 3 & 5200 & 32 \\
A2 & 2.200 .000 & 6.5 & 6 & 6000 & 128 \\
A3 & 3.000 .000 & 5.5 & 2 & 5000 & 64 \\
A4 & 2.700 .000 & 6.5 & 4 & 4000 & 64 \\
A5 & 3.690 .000 & 6.5 & 3 & 6000 & 64 \\
A6 & 2.700 .000 & 6 & 4 & 4000 & 32 \\
A7 & 4.000 .000 & 5.5 & 4 & 5000 & 64 \\
A8 & 6.000 .000 & 4 & 8 & 4000 & 64 \\
Max & $\underline{6.000 .000}$ & $\underline{6.5}$ & $\underline{8}$ & $\underline{6000}$ & $\underline{\underline{4}}$ \\
Min & $\underline{1.600 .000}$ & $\underline{\underline{3}}$ & $\underline{32}$ \\
\hline
\end{tabular}

Setelah data rating kecocokan di perolah, maka dilakukan perangkingan dengan menggunakan metode PSI, seperti pada langkah berikut.

1. Mencari Normalisasi matriks keputusan

$$
\mathrm{N}_{\mathrm{ij}}=\left[\begin{array}{ccccc}
1 & 0,923077 & 0,375 & 0,866667 & 0,25 \\
0,727273 & 1 & 0,75 & 1 & 1 \\
0,53333 & 0,846154 & 0,25 & 0,83333 & 0,5 \\
0,592593 & 1 & 0,5 & 0,66667 & 0,5 \\
0,433604 & 1 & 0,375 & 1 & 0,5 \\
0,592593 & 0,923077 & 0,5 & 0,666667 & 0,25 \\
0,4 & 0,846154 & 0,5 & 0,83333 & 0,5 \\
0,266667 & 0,613585 & 1 & 0,666667 & 0,5
\end{array}\right]
$$

Selanjutnya lakukan perhitungan dalam menghitung nilai yang telah dilakukan normalisasi

$\sum_{i=1}^{n} N_{\mathrm{ij}}=\mathrm{N}_{11}+\mathrm{N}_{21}+\ldots+\mathrm{N}_{\mathrm{nm}}$

Setiap nilai pada kolom dijumlahkan maka akan diperoleh hasil sebagai berikut : 


\section{JURNAL MEDIA INFORMATIKA BUDIDARMA}

Volume 5, Nomor 3, Juli 2021, Page 762-768

ISSN 2614-5278 (media cetak), ISSN 2548-8368 (media online)

Available Online at https://ejurnal.stmik-budidarma.ac.id/index.php/mib DOI 10.30865/mib.v5i3.2994

$$
\sum_{i=1}^{n} N_{\mathrm{ij}}=\left[\begin{array}{lllll}
4,546062 & 7,153846 & 4,25 & 6,53333 & 4
\end{array}\right]
$$

2. Carilah nilai rata-rata dari data yang dinormalisasikan

Tahap ini, berarti nilai dari data normal dari setiap atribut dihitung dengan persamaan berikut:

$$
\begin{aligned}
& \mathrm{N}=\frac{1}{n} \sum_{i=1}^{n} N_{\mathrm{ij}}=\left[\begin{array}{llllll}
\frac{1}{8} \times 3,116 & \frac{1}{8} \times 3,6 & \frac{1}{8} \times 5,75 & \frac{1}{8} \times 4,6 & \frac{1}{8} \times 5,75
\end{array}\right] \\
& \mathrm{N}=\left[\begin{array}{lllll}
0,568258 & 0,894231 & 0,53125 & 0,816667 & 0,5
\end{array}\right]
\end{aligned}
$$

3. Carilah nilai variasi preferensi

Pada Tahapan berikut ini dilakukan beberapa tahapan sebagai berikut:

$\phi_{j}=\sum^{n_{i=1}}\left[N_{11}-N\right]^{2}$

$\phi_{11}=\sum^{n_{i=1}}[1-0,568258]^{2}=0,1936$

$\phi_{21}=\sum^{n_{i=1}}[0,727273-0,894231]^{2}=0,1936$

Dengan melakukan perhitungan yang sama seperti diatas maka di peroleh matriks berikut ini

$\phi_{j}=\left|\begin{array}{ccccc}0,186401155 & 0,000832087 & 0,024414 & 0,0025 & 0,0625 \\ 1,637960735 & 0,011187081 & 0,047852 & 0,033611 & 0,25 \\ 0,001219732 & 0,002311413 & 0,079102 & 0,000278 & 0 \\ 1,087480104 & 0,011187081 & 0,000977 & 0,0225 & 0 \\ 0,018131609 & 0,011187081 & 0,024414 & 0,033611 & 0 \\ 1,087480104 & 0,000832087 & 0,000977 & 0,0225 & 0,0625 \\ 0,028310755 & 0,002311413 & 0,000977 & 0,000278 & 0 \\ 0,220214721 & 0,077755306 & 0,219727 & 0,0225 & 0\end{array}\right|$

Setelah mendapatkan matriks diatas kemudian dijumlahkan setiap kolomny

$$
\phi_{j}=\quad \begin{array}{lllll}
0,351490611 & 0,11760355 & 0,3984375 & 0,13777778 & 0,375
\end{array}
$$

Menentukan penyimpangan dapat dilakuakan rumus berikut

$\Omega_{\mathrm{j}}=1-\phi_{j}$

$\Omega_{1}=1-0,351490611=0,648509389$

$\Omega_{2}=1-0,11760355=0,88239645$

$\Omega_{3}=1-0,3984375=0,6015625$

$\Omega_{4}=1-0,13777778=0,862222222$

$\Omega_{5}=1-0,375 \quad=0,625$

Dengan melakukan perhitungan yang sama maka diperoleh :

$\sum_{n=1}^{m} \Omega_{\mathrm{j}}=(0,648509389+0,88239645+0,6015625+0,862222222+0,625)$

$\sum_{n=1}^{m} \Omega_{\mathrm{j}}=3,619690561$

4. Menentukan kriteria bobot

Bobot krtiteria digunakan untuk menentukan

$\mathrm{W}_{\mathrm{j}}=\frac{\phi j}{\sum_{n=1}^{m} \Omega \mathrm{j}}$

Maka nilai bobot kriteria

$$
\begin{aligned}
& \mathrm{W}_{1}=\frac{0,351490611}{3,619690561}=0,097105155 \\
& \mathrm{~W}_{2}=\frac{0,11760355}{3,619690561}=0,032489946 \\
& \mathrm{~W}_{3}=\frac{0,3984375}{3,619690561}=0,110075017 \\
& \mathrm{~W}_{4}=\frac{0,13777778}{3,619690561}=0,038063413 \\
& \mathrm{~W}_{5}=\frac{0,375}{3,619690561}=0,1036
\end{aligned}
$$

Dengan melakukan perhitungan yang sama seperti diatas maka di peroleh matriks berikut ini 

DOI 10.30865/mib.v5i3.2994

$\mathrm{X}_{\mathrm{ij}}=\left|\begin{array}{llllll}0,097105155 & 0,029990719 & 0,041278131 & 0,032988291 & 0,0259 \\ 0,070621931 & 0,032489946 & 0,082556263 & 0,038063413 & 0,1036 \\ 0,051789416 & 0,027491493 & 0,027518754 & 0,031719511 & 0,0518 \\ 0,057543796 & 0,032489946 & 0,055037509 & 0,025375609 & 0,0518 \\ 0,042105216 & 0,032489946 & 0,041278131 & 0,038063413 & 0,0518 \\ 0,057543796 & 0,029990719 & 0,055037509 & 0,025375609 & 0,0259 \\ 0,038842062 & 0,027491493 & 0,055037509 & 0,031719511 & 0,0518 \\ 0,025894708 & 0,019993813 & 0,110075017 & 0,025375609 & 0,0518\end{array}\right|$

5. Perangkingan

Setelah dilakukan perhitungan keseluruhan data ditotalkan berdasarkan masing-masing baris yang dimiliki alternatif terhadap kriteria, nilai tertinggi menunjukan data merek smartphone terbaik sebagai rekomendasi yang dipilih menggunakan tahapan metode PSI sehingga temukan hasil pada tabel 7 berikut ini.

Tabel 7. Hasil Rangking

\begin{tabular}{clcc}
\hline Kode & Nama alternatif & Nilai & Rangking \\
\hline A1 & Infinix & 0,227262 & 3 \\
A2 & Xiaomi & 0,327332 & 1 \\
A3 & Samsung & 0,190319 & 8 \\
A4 & Vivo & 0,222247 & 4 \\
A5 & Oppo & 0,205737 & 5 \\
A6 & Realme & 0,193848 & 7 \\
A7 & huwawei & 0,204891 & 6 \\
A8 & Iphone & 0,233139 & 2 \\
\hline
\end{tabular}

\section{KESIMPULAN}

Dari pembahasan di atas memperlihatkan beberapa kesimpulan diantaranya pada metode PSI sangat membantu peneliti dalam menentukan bobot masing-masing kriteria dengan beberapa tahapan sebagai bahan pertimbangan terhadap pemilihan alternatif yang akan diproses berdasarkan masing-masing nilai. Penerapan metode ini sangat sederhana dan sangat mudah dipahami karena setiap tahapan membantu dalam menghasilkan keputusan. Metode Penerapan Preference Selection Index (PSI) sangat membantu dalam menentukan pemilihan smartphone terbaik untuk kalangan mahasiswa dimasa era Covid-19 dengan alternatif X2 memiliki jenis terbaik pada nilai 0,327332.

\section{REFERENCES}

[1] N. R. Yunus and A. Rezki, "Kebijakan Pemberlakuan Lock Down Sebagai Antisipasi Penyebaran Corona Virus Covid19," SALAM J. Sos. dan Budaya Syar-i, vol. 7, no. 3, 2020.

[2] J. Kirana, K. P. Rajagukguk, E. Lailan, and S. Lubis, "ANALISIS DAMPAK COVID-19 PADA MASYARAKAT," vol. 1, pp. 64-69, 2020.

[3] J. Samuel, G. G. M. N. Ali, M. M. Rahman, E. Esawi, and Y. Samuel, "COVID-19 public sentiment insights and machine learning for tweets classification," Inf., vol. 11, no. 6, pp. 1-22, 2020.

[4] H. Jati, U. N. Cendana, R. F. Makatita, U. Mikro, and E. Kreatif, "Seminar Nasional Manajemen dan Call for Paper ( SENIMA 5 ) Dampak Covid 19 Terhadap UMK dan Pentingnya Literasi Keuangan dan Teknologi dalam Mempertahankan Kelangsungan Bisnis Kuliner di Kota Kupang,” no. January, 2021.

[5] S. AMILIA, "Pengaruh Citra Merek, Harga, dan Kualitas Produk terhadap Keputusan Pembelian Handphone Merek Xiaomi di Kota Langsa," J. Manaj. dan Keuang. Unsam, vol. 6, no. 1, pp. 660-669, 2017.

[6] T. Hasanah, B. Aviani, and A. T. Hidayat, "Sistem Pendukung Keputusan Seleksi Pemberian Uang Kuliah Tunggal Menerapkan Metode WASPAS,” vol. 2, no. September, pp. 102-109, 2020.

[7] M. Mesran, N. Huda, S. N. Hutagalung, K. Khasanah, and A. Iskandar, "SISTEM PENDUKUNG KEPUTUSAN PEMILIHAN SUPERVISOR TERBAIK PADA BAGIAN PERENCANAAN PT. PLN (PERSERO) AREA MEDAN MENERAPKAN PREFERENCE SELECTION INDEX," KOMIK (Konferensi Nas. Teknol. Inf. dan Komputer), vol. 2, no. 1 , Oct. 2018

[8] Y. Ali and Aprina, "Penerapan Metode Preference Selection Index ( PSI ) Dalam Pemberian Dana BOS Pada Siswa Kurang Mampu,” Semin. Nas. Teknol. Komput. Sains, no. 1, pp. 590-597, 2019.

[9] R. Panggabean and N. A. Hasibuan, "Penerapan Preference Selection Index ( PSI ) Dalam Sistem Pendukung Keputusan Pengangkatan Supervisor Housekeeping," Rekayasa Tek. Inform. dan Inf., vol. 1, no. 2, pp. 85-93, 2020.

[10] N. P. Rizanti, L. T. Sianturi, and M. Sianturi, "Sistem Pendukung Keputusan Pemilihan Siswa Pertukaran Pelajar Menggunakan Metode PSI (Preference Selection Index)," Semin. Nas. Teknol. Komput. dan Sains, pp. 263-269, 2019.

[11] M. K. Siahaan, M. Mesran, S. A. Hutabarat, and J. Afriany, "Sistem Pendukung Keputusan Penentuan Prioritas Pembangunan Daerah Menerapkan Metode Preference Selection Index (Psi)," KOMIK (Konferensi Nas. Teknol. Inf. dan Komputer), vol. 2, no. 1, pp. 370-375, 2018.

[12] Albi Anggito and Johan Setiawan, Metodologi Penelitian Kuantitatif. Jawa Barat: CV Jejak, 2018.

[13] J. M. Corchado, J. F. De Paz, S. Rodríguez, and J. Bajo, "Model of experts for decision support in the diagnosis of leukemia patients," Artif. Intell. Med., vol. 46, no. 3, pp. 179-200, 2009. 
[14] E. Kılıç Delice, G. F. CAN, and E. KAHYA, "improving the rapid office strain assessment method with an integrated multi-criteria decision making approach," Gazi Üniversitesi Mühendislik-Mimarlık Fakültesi Derg., no. September, 2020.

[15] T. Limbong et al., Sistem Pendukung Keputusan: Metode \& Implementasi. Medan: Yayasan Kita Menulis, 2020.

[16] Efraim Turban and Jay E. Aronson, Decision Support System and Intelligent Systems. 2001.

[17] D. Nofriansyah and S. Defit, Multi Criteria Decision Making (MCDM) pada Sistem Pendukung Keputusan. 2018.

[18] K. Arizona, Z. Abidin, and R. Rumansyah, "Pembelajaran Online Berbasis Proyek Salah Satu Solusi Kegiatan Belajar Mengajar Di Tengah Pandemi Covid-19," J. Ilm. Profesi Pendidik., vol. 5, no. 1, pp. 64-70, 2020.

[19] F. Syahputra, M. Mesran, I. Lubis, and A. P. Windarto, "Sistem Pendukung Keputusan Pemilihan Guru Berprestasi Kota Medan Menerapkan Metode Preferences Selection Index (Studi Kasus : Dinas Pendidikan Kota Medan)," KOMIK (Konferensi Nas. Teknol. Inf. dan Komputer), vol. 2, no. 1, pp. 147-155, 2018.

[20] R. Attri and S. Grover, "Application of preference selection index method for decision making over the design stage of production system life cycle,” J. King Saud Univ. - Eng. Sci., vol. 27, no. 2, pp. 207-216, 2015.

[21] S. H. Sahir et al., "The Preference Selection Index Method in Determining the Location of Used Laptop Marketing," Int. J. Eng. Technol., vol. 7, pp. 260-263, 2018.

[22] Mesran, K. Tampubolon, R. D. Sianturi, F. T. Waruwu, and A. P. U. Siahaan, "Determination of Education Scholarship Recipients Using Preference Selection Index," Int. J. Sci. Res. Sci. Technol., vol. 3, no. 6, pp. 230-234, 2017. 